\title{
ASSESSING CUSTOMER DEMAND AND CUSTOMER SATISFACTION THROUGH SOCIAL AND ENVIRONMENTAL PRACTICES IN THE HOTEL SECTOR OF BANGLADESH
}

\author{
Rashed AI KARIM* \\ School of Business Administration, East Delta University, Noman Society, East Nasirabad, Khulshi, \\ Chittagong: 4209, Bangladesh, e-mail: alkarim.rashed@gmail.com \\ Mohammad Wahidul ISLAM \\ School of Business Administration, East Delta University, Noman Society, \\ East Nasirabad, Khulshi, Chittagong, 4209, Bangladesh, e-mail: wahid@ eastdelta.edu.bd
}

\begin{abstract}
Citation: Karim, R.A., \& Islam, M.W. (2020). ASSESSING CUSTOMER DEMAND AND CUSTOMER SATISFACTION THROUGH SOCIAL AND ENVIRONMENTAL PRACTICES IN THE HOTEL SECTOR OF BANGLADESH. GeoJournal of Tourism and Geosites, 30(2spl), 843-851. https://doi.org/10.30892/gtg.302spl09-513
\end{abstract}

\begin{abstract}
This study aims to assess the customer demand and satisfaction through social and environmental CSR practices based on tourist's perception in Bangladesh hotel sector. Data were collected through the survey questionnaire across the three famous tourist destination cities (Dhaka, Chittagong and Cox's bazar) of Bangladesh. The valid sample size of this study was 402 and respondents were selected executing systematic sampling technique. Data were analysed through SmratPLS 3.0 software. From the findings, it was found that both social and environmental CSR has a positive association with customer demand, whereas, only social CSR is positively associated with customer satisfaction and environmental CSR has no significant association with customer satisfaction. Also, customer demand positively associated with customer satisfaction.
\end{abstract}

Key words: : Corporate Social Responsibility; Social CSR; Environmental CSR; Customer Demand; Customer Satisfaction

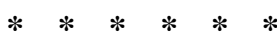

\section{INTRODUCTION}

According to the up-to-date UNWTO World Tourism Barometer (2019), the arrivals of global tourist have already reached 1403 million in 2018, 74 million more than in 2017 (1329 million), with an increase of 6\% from the earlier year, which is the ninth successive annum of maintaining above average growth since the economic crisis in 2009. The forecasting of contribution of international tourism for 2018 by UNWTO is increased by $4 \%$ to $5 \%$, which additionally contributed to the recovery from the international economic crisis. In addition, UNWTO, (2019) acknowledged that by making billions of dollars in exports in conjunction with offering millions of employments, tourism and hospitality industry has established itself as a major contributor to the world economy by its resilient economic activities. Thus, the effect of tourism and hospitality industry on the global economy is increasing significantly and becoming one of the sectors within the universe with the rapidest growth ever (de Leaniz and del Bosque, 2015). However, the scope and magnitude of the sector's growth has already raised several questions regarding its negative impacts, not only from an economic viewpoint, but also from environmental and socio-cultural perspectives. Due to the nature of the business, this industry largely depends on the environmental and cultural resources at destinations. Therefore, for attaining long-term corporate sustainability by minimising the negative impacts on the society and the environment, it is necessary for the leading hotel companies to scrutinize the ultimate operative ways in strengthening and extending their approach towards hotel CSR activities, because the notion of CSR limits firms in integrating social and environmental issues in their day-to-day business operations and in interacting with their stakeholders voluntarily (Fatma et al., 2016).

In today's competitive marketplace, CSR has become mainstream in the corporate world (Torreli et al., 2011) including those in the tourism and hospitality industry where interest in CSR has grown since the first decade of the 21st century (Kang et al., 2015). Many firms from the hospitality industry have identified the necessity for maintaining stability between a firm's profitability and its reputation to the community, the government and the general society as well as the environment (Mozes et al., 2011). There are numerous economic, social and environmental benefits that can accrue to the industry from wider adoption of CSR (Benavides-Velasco et al., 2014). This management concept can help the industry become more environmentally sustainable, uphold higher retention percentage of customers, have a higher rate of employee retention, and ultimately, contribute towards a country's GDP (Lee et al., 2012; Chan, 2011). The ultimate goal for hotels in adopting this flexible approach is to benefit from CSR related benefits such as cost reduction, improvement of organisation image and reputation, and reduction of pressure from the government (Kasim, 2015).

Unlike several developed and developing countries in the world, CSR is not a compulsory requisite for all business organisations to practice and report in Bangladesh (Belal and Cooper, 2011). Prior studies by Muttakin and Khan (2014), Belal and Owen (2007), Islam and Deegan's (2008) research on CSR show that CSR studies within Bangladesh context still focus solely on the multinational corporation (MNCs) in the manufacturing, readymade garments and banking sector. Moreover, earlier studies (Ullah and Rahman 2015; Haque and Azmat, 2015; Momin and Parker, 2013; Belal and Roberts, 2010; Ahmed and Peerlings, 2009; Belal, 2008; Paul-Majumder and Begum, 2006; Nielsen, 2005) have mostly concentrated on the social and environmental disclosures/reporting based on secondary data such as the annual reports of financial sectors and MNC's from Bangladesh. Hardly any study has been done on CSR using primary data, particularly to understand tourist demand regarding CSR practices in Bangladesh's hotel sector. In addition to these, any study focusing on CSR related issues in the hospitality sector is rarely found. Hence it is important to explore why this is so. What are the extents of demands, if any, of customer/tourist/guests while staying in hotels that implement CSR compared to those that do not? How satisfied the customers/tourists are during their stay in the hotel of Bangladesh? These are the precise questions that drove this study to attempt to assessing the customer satisfaction and demand through social and environmental CSR practices in Bangladesh's Hotel Sector.

\footnotetext{
* Corresponding author
} 
Moreover, stakeholder theory has been chosen as the theoretical foundation to exploring the customer satisfaction and customer demand through CSR practices by Bangladesh's hotel sector. Stakeholder theory suggests a firm's endurance and achievement is contingent on gratifying not only its economic (e.g., profit maximisation) objectives but also its non-economic (e.g., social and environmental concerns) objectives by meeting the needs of the company's various stakeholders (Pirsch et al., 2007). Since stakeholder theory redefines an organization as the alliance of various stakeholders (Clarkson, 1995), the drive of the organization must therefore be to conserve the interests, requirements, and perspectives of these diverse stakeholders. As a result, top managements are responsible for achieving the stakeholders' benefits so as to confirm their privileges and contribution in the process of decision making (Mensah, 2014). It is also essential for businesses to specify their stakeholders' needs and to endeavour to come across their least expectations (Kotler et al., 2006). In addition, to validate the existence of the firm and to uphold the long-term stakes of every stakeholder, management must act as the agent of organization's stockholders. For that reason, with stakeholder theory, the success of a firm depends on how effectively the management accomplishes the affiliations with its stakeholders (Elijido-Ten, 2007). Besides, numerous authors have also preferred the stakeholder approach while investigating social responsibilities, environmental responsibilities or both in different businesses (Jamali, 2008). Accordingly, this study also employs stakeholder theory to assess the customer demand as well as customer satisfaction through social and environmental CSR practices in the hotel sector of Bangladesh, as customers are an additional source of stakeholders' demand for firm's social and environmental responsible activities. The rationales behind choosing Bangladesh are: firstly, undertaking an empirical study of CSR in a less developing country like Bangladesh might improve the broad understanding of corporate social responsibility. Secondly, despite Bangladesh being considered as a less developed country, it made notable progress in economic performance during the 1900s and into the twenty-first century, as it began to embrace a more open economy and became more integrated with global economic markets (Belal and Roberts, 2010).

So, economic growth and a shift to a global market economy are associated with the demand for socially and environmentally responsible activities. Thirdly, it is hoped that this study will comprehensively offer some unique and useful insights concerning CSR in the less developing country context and the perceptions of its relevant stakeholder towards CSR practices. Eventually, the findings of this study would positively contribute towards the sustainable growth of Bangladesh hospitality industry.

\section{LITERATURE REVIEW \& HYPOTHESIS DEVELOPMENT}

\section{CSR Practice in Hospitality Industry}

Over the last few decades, the notion of the CSR has gained popularity due to the increasing consciousness of the social and environmental concerns during the operation of their business by the stakeholders. A growing number of the companies already declared their dedication to ethical, social and environmentally accountable principles. Their devotion towards CSR practices confirms their businesses are CSR-driven and they also provide CSR activity details in company annual reports. However, many researchers from this field such as Martínez and del Bosque (2014); Bohdanowicz and Zientara (2009), and McGehee et al., (2009) mentioned in their earlier study that the awareness of CSR within the tourism and hospitality industry context got surprisingly little attention in the academic literature. Although, in today's hospitality industry, many researchers and professionals come to an agreement that for the success of the business in this field, CSR practices have already been established as an essential business function. That is why several investigators, such as Pereira-Moliner et al., (2015), Inoue and Lee (2011), and Kang et al., (2010), are concentrating on identifying the relationship between the companie s' financial performance and their CSR practices to clarify exactly how CSR is considered in this industry and what its role is as well as how it is to be executed within the industry. These days, o one hand, hospitality industry is considered a major source of economic, social and environmental benefits, on the other hand, this industry creates a massive number of negative impacts on society and environment. According to Hsieh (2012), even if the hospitality industry is considered as one of the key contributors to the economy in terms of revenue generation and employment opportunity, the industry is also continuously causing several negative impacts on the environment besides benefits. Hence, the author specified that the hotel industry is concerned about the following issues: waste recycling and management, air contamination, conservation of water and energy, health and safety, infrastructure of hotel building and its permission, agreement with rules and regulations, eco-purchasing, environmental education and climate changes (Hsieh, 2012). Initially, the hotel industry paid less attention than heavy polluters like chemical industries, manufacturing industries. Presently the concerns of consumers along with general public are increasing towards the negative impacts of hotel industry and becoming progressively attentive about the efforts undertaken by the hotel industry to mitigate them. Moreover, various international tourism organisations such as World Travel and Tourism Council (WTTC), World Tourism Organization (WTO) and Earth Council (EC) are becoming increasingly active in executing Agenda 21 regarding responsible and sustainable matters of tourism and hospitality industry (Khairat and Maher, 2012).

\section{CSR and Customer Demand}

As many researchers such as Bohdanowicz and Zientara (2009), Chung and Parker (2010), Cuccia and Rizzo (2011), Jovicic (2011) and Liu and Lin (2011) have already mentioned in their respective study that the hospitality industry is repeatedly considered as the foundation of economic, social and environmental benefits by creating jobs for the local community, by improving local infrastructures, by protecting local heritage and also by developing a relationship with local business, communities, and government. Oppositely, this industry has also created lots of negative impacts on society and environments, including massive amounts of water and energy consumption, air and noise pollution, waste generation, loss of biodiversity, etc. (Chan, 2011; Khairat and Maher, 2012). To agree with Font et al., (2012), an organization does not only focus its responsibilities on the legal and economic dimensions, but it does also extend these to the social and the environmental aspects. Thus, stakeholders should demonstrate an increasing demand not only in terms of generating profits, providing quality services and maintaining lucrative structures on the whole but also about urging further to take necessary initiatives to industry to protect resources, society, culture, and environment at large of the destinations (Bigné et al., 2000).

According to Eltayeb et al. (2010), customer demands are the pressure or desires enforced by procuring firms or individuals identifying definite requirements in products and amenities. Moreover, consumers are plausibly considered as a common category stakeholder who creates pressure or increases demand on an organization when they believe that firms are not behaving in a socially responsible way (Lindgreen et al., 2009). So, if a firm's activities fail to influence consumers' moral values, firms may lose their prospective customers and business to other rivals. The reactions and movements of consumers, contrary to firms' socially responsible or irresponsible practices, limit a firm to modify their assertiveness and tactic toward CSR (Yang and Rivers, 2009). Therefore, firms should endeavour to address the preferred and needed values of the society where they are functioning to lure and retain customers. In the case of the hotel industry, Kirk (1998) stressed that the majority of hoteliers would be bound to respond to the pressure/demands from the customers or the society. For example, along with the manager from Hotel Melia, consumers or guests are more conscious about the environment where they travel and stay. Eco destinations and green hotels are the ultimate preferences of their stay (Yusof and Jamaludin, 2013). 
Conversely, to Butler (2008), if the hotels are not able to adopt environmentally responsible practices, hoteliers might lose their prospective customers to other green operators. Bohdanowicz (2005) further found in the European hotel industry that customer demands are the key influential motivation for hotels to execute environmentally friendly practices. Due to the increased customers' cons ciousness, hoteliers are becoming more responsive to their social and environmental, including eco-friendly products, services, and purchasing (Bohdanowicz, 2005). Moreover, customers who are socially responsible will evade purchasing products and services from hotel firms that are harmful to society and the environment and will keenly seek substitute products and services from other firms that provide supports to the community, society, and environment at large (Yang and Rivers, 2009). Customers may also have lethal effects on hotel firms that have negative connotations with social and environmentally friendly activities in contrast to positive implications, which help to boost firms' reputation and image in the society (Brown and Dacin, 1997; Yang and Rivers, 2009). In this regard, Bohdanowicz (2005) recognized consumer awareness as a critical driver of hotel adoption of CSR initiatives, and day by day, the increased consumer awarenes s of CSR efforts may lead to more hotel guest demand. To scrutinize the role of hotel CSR practices (social and environmental) further in the current study, we proposed the following hypotheses:

$\mathbf{H}_{\mathbf{1}}$ : A hotel's social CSR practice is positively associated with customer demand.

$\mathbf{H}_{\mathbf{1 b}}$ : A hotel's environmental CSR practice is positively associated with customer demand.

\section{CSR and Customer Satisfaction}

In agreement with Luo and Bhattachara (2006), customer satisfaction is a comprehensive evaluation based on customers' total purchase and the intake experience of products or services of a firm over time. Bowen and Clarke (2002) acknowledged satisfaction as one of the critical judgments of customers make about a product or service, and mostly, is an engrained, long-lasting focal point for marketer attention (Bowen \& Clarke, 2002). Customer develops a positive behavioural intent to uphold a level of satisfaction when they are satisfied with a product or service (Hsu, 2012; Ahmad et al. 2019). In explaining the nebulous connexion between CSR and the market value of a firm, Luo and Bhattacharya (2006) emphasize the importance of consideration of customer satisfaction as an evaluative consequence of CSR. Similarly, Awang and Jusoff (2009) considered customer satisfaction as one of the principal components of a competitive advantage which a business firm can achieve through their social and environmental performances. In the context of the hospitality sector, Kasim (2015) uttered that if hoteliers can fulfil their customer/tourist/guest's demand (what they want or expect from your hotel) through their environmentally friendly services and activities, then their satisfaction level will be high. If they are satisfied, then they will visit again and again, and in return, the financial performance of the hotel will thrive. They also found that well-established hotel environmental guidelines and an active EMS that links community, the hotel employee and public relations will improve the organizational image and indirectly enhance guest satisfaction. Moreover, several previous studies such as Saeidi et al., 2015; Benavides-Velasco et al., 2014; Basu and Palazzo, 2008; Senthikumar et al. (2011) found the similar relationship that customer satisfaction and organization's CSR activities are positively related to each other. For example, Cherapanukorn and Focken (2014) claimed that due to the adoption of effective CSR practices, the hotel industry is achieving various substantial business-related benefits, including customer satisfaction for their eco-friendly services. Also, Senthikumar et al. (2011), and Luo and Bhattachara (2006) discovered that CSR practices provide positive effects to the aspects of organizational performance where the satisfaction of customers is one of them. Moreover, Benavides-Velasco et al. (2014) emphasized that CSR is a concept that should be embedded into the organizational culture to improve firms' financial performances, enrich corporate image/reputation, and create customer satisfaction. Thus, based on the thoughts as mentioned earlier, the proposed hypotheses are:

$\mathbf{H}_{2 \mathrm{a}}$ : A hotel's social CSR practice is positively associated with customer satisfaction

$\mathbf{H}_{2 \mathbf{b}}$ : A hotel's environmental CSR practice is positively associated with customer satisfaction

\section{Customer Demand \& Customer Satisfaction}

Based on earlier studies, KamalulAriffin et al., (2013) defined customer demand as desires enacted by procuring firms or individuals identifying some specific requirements in products and services. They further mentioned that customer demand has a particular influence on an organization's socially and environmentally responsible decisions. Moreover, Kasim (2004) stated in her study that the number of demanding and conscious customers is progressively increasing, who were ready to accept the modes of behaviour that are more suitable to the environment of the receiving destinations. Conversely, there had little empirical evidence on consumer demand for socially and environmentally responsible tourism. From those few evidence, a study based on the green hotels in Washington, Gustin and Weaver (1994) found that the majority of respondents $(73 \%)$ recognized themselves as environmentally friendly consumers, whereas 71 percent of the respondents specified willingness to stay in a green hotel. Besides, from the findings of her study, Kasim (2004) found little empirical evidence on the rise of the consumer demand for environmentally and socially responsible hotels.

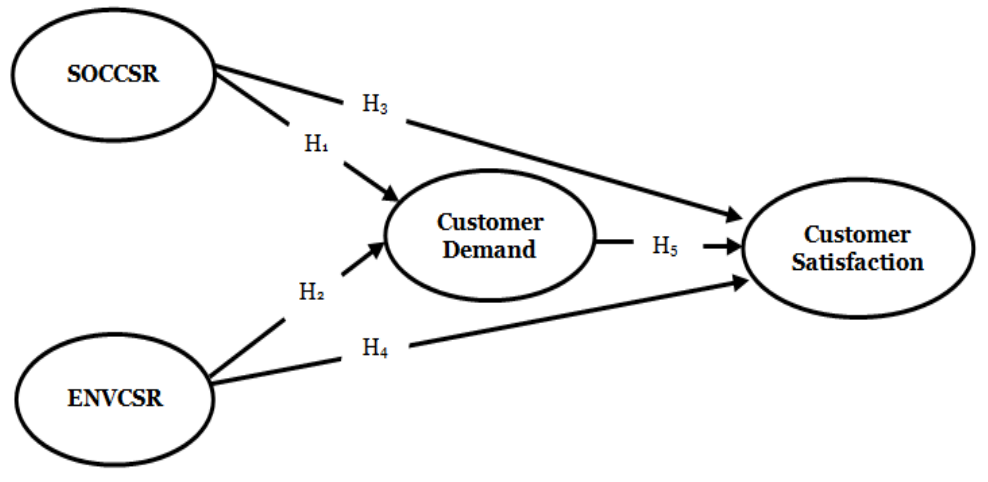

Figure 1. Conceptual Framework

In the same way, SitiNabiha et al., (2010) pointed out in their study, more than a few researchers have identified those business firms that embraced environmental management practices driven by customer demand. Karim (2019) revealed that the fundamental reasons for a hotel to "go green" were governmental pressures and the desire to preserve resources by conserving waste, energy, and water. Recent 
research, however, finds that guests now demand environmental attributes in hotels and because of this demand, hoteliers need to uphold environmental initiatives. Recent studies also have shown that some hotel green attributes do contribute to enhance overall guest satisfaction. Robinot and Giannelloni (2010) also found that some green attributes can be expected as part of the service offer and, therefore, are not viewed as differentiating criteria by the customer. For example, customers evaluated the reuse of linens and towels as a basic attribute that they expected from hotels, and the absence of such an attribute was considered to have a negative effect on guest satisfaction. Conversely, the study also showed that if a hotel used clean and renewable energy sources, customers considered it as a "plus" attribute, which increased their satisfaction levels and contributed to the hotel's competitive advantage.

In addition to these, Creyer and Ross (1997) found that responsible corporate activities were preferential by customers as well as considered as an essential aspect in the process of purchase decision making. The study also revealed that consumers' demand might be comparatively more price inelastic for products or services offered by the business firms who were involved in CSR activities. Such CSR activities have been evidenced to impact customer demands resulting in a higher degree of customer satisfaction (Galbreath, 2010; Lee et al., 2012). Last but not least, in line with Liat et al., (2014), hoteliers should focus on customer needs and demands and integrate the hotel services that affect customer satisfaction, as their satisfaction plays a noteworthy role in the image of the firm. Also, sat isfied customers will have revisiting intentions near the future, so hotel operators should concede the demands of the customer to strengthen the satisfaction of the customer. As per the above reviews, the proposed hypothesis is:

\section{$\mathbf{H}_{3}$ : Customer demand is positively associated with customer satisfaction}

\section{RESEARCH METHODS}

\section{Data Collection, Sampling Technique \& Sample Size}

The data of this study were collected through structured questionnaire among hotel guests to illustrate the current scenario of tourist demand regarding the hotel CSR practices in Bangladesh. The systematic probability sampling was chosen to select target respondents from Dhaka and Chittagong division where one specific city from Chittagong division, namely, Cox's Bazar, is the most famous tourist destination in Bangladesh (Table 1). And the reason for choosing systematic sampling technique is- a complete list of the total population is not mandatory always when using systematic sampling (Saunders et al., 2012) and the sample element listing was available conveniently at one place e.g., telephone directory, company payroll, hotel register, chamber of commerce listings (Sekaran, 2003).

According to Bangladesh Tourism Board and Bangladesh Parjatan Corporation, the total number of foreign tourists arrived in Bangladesh were 620,000 i.e., 0.62 million in 2016 and based on Krejcie and Morgan's (1970) assumption, the sample size for this study was 384. A total of 500 questionnaires were, therefore, distributed in the three cities. Hence the ratio of the total room occupancy (3016) and the distributed questionnaires (500) is 6.032. Thus, in this study, every sixth $\left(6^{\text {th }}\right)$ room's respondent was chosen for the survey regardless of country of origin. Besides, one vital aspect of probability sampling during the data collection was respondents' response rate, i.e. a perfect representative sample. Therefore, taking the prior studies response rate in mind, a total of 402 questionnaires were found acceptable for analysis for this study which represents $80.4 \%$ rate of response.

Table 1. Number of Destinations in Bangladesh (Data Source: BPC, 2007)

\begin{tabular}{|l|l|ll|}
\hline East & Middle & West & \\
\hline Sylhet & Mymenshing & Dinajpur & Naogon \\
Comilla & Tangail & Khulna & Bagerhat \\
Chittagong & Gazipur & Rajshahi & \\
Khagrachari & Narsingdi & Natore & \\
Rangamati & Dhaka & Bagora & \\
Bandarban & Narayngang & Kushtia & \\
Cox's Bazar & Patuakhali & Jessore & \\
\hline
\end{tabular}

Table 2. Measurement of Construct \& its Reliability and Validity

\begin{tabular}{|c|c|c|c|c|c|c|}
\hline \multicolumn{7}{|c|}{ Construct Reliability and Validity } \\
\hline Constructs & & Items & Loading & $\alpha$ & $\mathrm{CR}$ & AVE \\
\hline \multirow{6}{*}{$\begin{array}{l}\text { Social CSR } \\
\text { [Items adapted from } \\
\text { Zupan and Milfelner, } \\
\text { (2014); Zhu et al., } \\
(\mathbf{2 0 1 6 ) ]}\end{array}$} & SOC1 & Built in a style that fits into the cultural environment in which it is situated & 0.849 & \multirow[t]{6}{*}{0.888} & \multirow[t]{6}{*}{0.915} & \multirow[t]{6}{*}{0.641} \\
\hline & SOC2 & Serves locally produced food and drinks & 0.750 & & & \\
\hline & SOC3 & Employs staff from the local workforce & 0.800 & & & \\
\hline & SOC4 & Introduces guests to the local customs \& traditions and asks to respect them & 0.815 & & & \\
\hline & SOC5 & Provides eco-friendly and essential services to the guests for $24 / 7$ & 0.780 & & & \\
\hline & SOC6 & Fairly resolves guests' complaints and disputes for their satisfaction & 0.808 & & & \\
\hline \multirow{5}{*}{$\begin{array}{l}\text { Environmental CSR } \\
\text { [Items adapted from } \\
\text { Berezan et al., (2014)] }\end{array}$} & ENV1 & uses key card to turns on \& off power & 0.840 & \multirow[t]{5}{*}{0.856} & \multirow[t]{5}{*}{0.895} & \multirow[t]{5}{*}{0.633} \\
\hline & ENV2 & uses energy efficient light bulbs & 0.700 & & & \\
\hline & ENV3 & uses occupancy sensors to control lighting & 0.809 & & & \\
\hline & ENV4 & uses water saving devices in guest rooms & 0.863 & & & \\
\hline & ENV5 & encourages guests to reuse towels \& bed linen & 0.757 & & & \\
\hline \multirow{4}{*}{$\begin{array}{l}\text { Customer Demand } \\
\text { [Items adapted from } \\
\text { Tingchi Liu et al., } \\
(\mathbf{2 0 1 4 ) ]}\end{array}$} & CD1 & expected to provide full \& exact information about its products/services to customers & 0.822 & \multirow[t]{4}{*}{0.876} & \multirow[t]{4}{*}{0.915} & \multirow[t]{4}{*}{0.730} \\
\hline & $\mathrm{CD} 2$ & expected to give highest importance to their customers' satisfaction & 0.893 & & & \\
\hline & CD3 & should comply with legal regulations fully and promptly & 0.887 & & & \\
\hline & CD4 & $\begin{array}{l}\text { must uphold protocol to prohibit illegal practices within the hotel premises } \\
\text { (e.g. pornography, gambling and drug abuse) }\end{array}$ & 0.812 & & & \\
\hline \multirow{3}{*}{$\begin{array}{l}\text { Customer Satisfaction } \\
\text { [Items adapted from Han } \\
\text { et al., (2011)] }\end{array}$} & CS1 & Overall, I am happy with my decision to stay at this hotel. & 0.822 & \multirow[t]{3}{*}{0.808} & \multirow[t]{3}{*}{0.886} & \multirow[t]{3}{*}{0.722} \\
\hline & CS2 & I believe I did the right thing when I stayed at this hotel. & 0.883 & & & \\
\hline & CS3 & Overall, I am satisfied with the decision to stay at this hotel. & 0.843 & & & \\
\hline
\end{tabular}

\section{Measurement of Constructs}

To discover the association among customer satisfaction, customer demand towards hotel CSR practices in Bangladesh, a survey questionnaire was used for data collection, which contains all the variables of interest such as social CSR, environmental CS R, customer demand as well as satisfaction. The associated measurements of study variables were presented in Table 2. 
Based on the current infrastructures and facilities available in Bangladesh's hotel sector towards CSR practices, this study has adapted six items from Zupan and Milfelner (2014) and Zhu et al. (2016). To measure the environmental CSR (ENVCSR), five items were carefully chosen to measure from Berezan et al. (2014). On the other hand, the customer demand (CD) indicated tourists/hotel guests' awareness and needs regarding the socially and environmentally responsible activities performed by Bangladesh's hotel sector. Hence, to scrutinize hotel customer demand in Bangladesh perspective, four items were adapted from Tingchi Liu et al. (2014). And lastly, to measure customer satisfaction (CS), three items were chosen from Han et al. (2011). Moreover, all the items to measure the study constructs were selected on a 5 point scale of "Strongly Disagree" (1) to "Strongly Agree" (5).

\section{Findings}

\section{Respondents Demographic Profile}

The demographic profile contains five characteristics namely: gender, age, education, employment, and purpose of the visit (table 3 ).

Table 3. Sample Characteristics $(\mathrm{N}=402)$

\begin{tabular}{|c|c|c|c|c|c|c|c|}
\hline & Category & $\mathbf{N}$ & $\%$ & & Category & $\mathbf{N}$ & $\%$ \\
\hline \multirow[t]{2}{*}{ Gender } & Male & 232 & 57.7 & \multirow{5}{*}{ Job Status } & Student & 147 & 36.6 \\
\hline & Female & 170 & 42.3 & & Professional & 145 & 36.1 \\
\hline \multirow{5}{*}{ Age Group } & 18 to 25 Yrs & 134 & 33.3 & & Self-employed & 69 & 17.2 \\
\hline & 26 to 35 Yrs & 131 & 32.6 & & Unemployed & 19 & 4.7 \\
\hline & 36 to 49 Yrs & 85 & 21.1 & & Others & 22 & 5.5 \\
\hline & 50 to 65 Yrs & 40 & 10.0 & \multirow{5}{*}{$\begin{array}{l}\text { Purpose of } \\
\text { Visit }\end{array}$} & Visit Relatives & 26 & 6.5 \\
\hline & Over 65 Yrs & 12 & 3.0 & & Business & 51 & 12.7 \\
\hline \multirow{5}{*}{ Education } & Secondary & 4 & 1.0 & & Holiday & 201 & 50.0 \\
\hline & H. Secondary & 27 & 6.7 & & Study & 72 & 17.9 \\
\hline & Bachelor & 196 & 48.8 & & Conference/ Meeting & 52 & 12.9 \\
\hline & P. Graduate & 168 & 41.8 & & & & \\
\hline & Vocational & 7 & 1.7 & & & & \\
\hline
\end{tabular}

From 402 respondents, $57.7 \%$ were male and $42.3 \%$ percent were female and regarding age, $33.3 \%$ were from the age group 18 to 25 years while $32.6 \%$, from age group 26 to 35 years and then $21.1 \%$ from 36 to 49 years, $10 \%$ from 50 to 65 years and only $3 \%$ from the age group of over 65 years. In terms of educational qualification, around forty nine percent $(48.8 \%)$ of respondents completed their bachelor's degree whereas $41.8 \%$ completed their post-graduation degree, $6.7 \%$ higher secondary, $1.7 \%$ vocational and $1 \%$ completed their secondary study. With respect to employment, $36.6 \%$ i.e. 147 respondents were student, followed by $36.1 \%$ professional, $17.2 \%$ self-employed, $4.7 \%$ unemployed and 5.5\% were from other categories. And about their purpose of visit, the highest $50 \%$ respondents were found for enjoying their holiday or leisure however $17.9 \%$ visited for study purposes, $12.9 \%$ visited for attending conference or meeting, $12.7 \%$ travelled for business purposes, and the lowest percentage i.e. $6.5 \%$ were found to visit their friends or relatives.

\section{Assessment of Measurement Model}

On the word of the Hair et al. (2017) and Henseler et al. (2009), the value for individual item loading should be greater than 0.70 , however, Vinzi et al. (2010) recommended the outer loadings must be 0.5. Hence the outer loadings of all the items of the study constructs were above 0.7 and fulfilled the aforesaid cut-off value. Moreover, all the latent constructs' composite reliability values have met and exceeded the cut-off value of 0.70 as stated by Hair et al. (2017). Likewise, in keeping with Hair et al. (2017) and Chin's (1998) recommendations, to achieve the acceptable level of convergent validity, the AVE of each latent construct must be greater than 0.50 or above. The result unveils that all the constructs AVE value is higher than 0.50 (Table 1) and exceeded the minimum cut-off value suggested by Chin (1998) and Hair et al. (2017). And lastly, in assessing discriminant validity, it was found that the square root of the AVE of each latent variable (the bold diagonal values) is higher than the correlations of the latent variables (the un-bolded diagonal values) and accomplishes Fornell and Larcker's (1981) criterion and indicating acceptable discriminant validity (Table 4). Into the bargain, Henseler et al. (2015) suggested another method of assessing discriminant validity, named Heterotrait-Monotrait (HTMT) Ratio of correlations with a threshold value of 0.90 , that is, an HTMT value greater than 0.90 recommends a lack of discriminant validity. Thus, finding showed that all the correlation values among the latent constructs are less than the suggested threshold value of .90 and confirmed that all the constructs are distinct from each other and obtained the discriminant validity on the basis of HTMT technique (Table 5).

Table 4. Discriminant Validity

\begin{tabular}{|c|c|c|c|c|}
\hline \multicolumn{5}{|c|}{ Fornell and Larcker Criterion } \\
\hline & $\mathrm{CD}$ & $\mathrm{CS}$ & ENVCSR & SOCCSR \\
\hline CD & 0.854 & & & \\
\hline CS & 0.557 & 0.850 & & \\
\hline ENVCSR & 0.722 & 0.531 & 0.795 & \\
\hline SOCCSR & 0.657 & 0.573 & 0.763 & 0.801 \\
\hline
\end{tabular}

Table 5. Heterotrait-Monotrait Ratio (HTMT)

\begin{tabular}{|l|l|l|l|}
\hline & CD & CS & ENVCSR \\
\hline CD & & & \\
\hline CS & 0.653 & & \\
\hline ENVCSR & 0.797 & 0.608 & \\
\hline SOCCSR & 0.730 & 0.659 & 0.858 \\
\hline
\end{tabular}

\section{Assessment of Structural Model}

From the path analysis of direct relationship (Table 6$)$, it was revealed that the social $\operatorname{CSR}(\beta=0.254, \mathrm{t}=3.684$, $\mathrm{p}<0.05)$ and environmental CSR $(\beta=0.528, t=9.052, p<0.05)$ were positively and significantly associated with customer demand regarding hotel CSR practices. Conversely, only social CSR $(\beta=0.328, \mathrm{t}=4.027, \mathrm{p}<0.05)$ was positively and significantly associated with customer satisfaction while environmental $\operatorname{CSR}(\beta=0.071, \mathrm{t}=0.929, \mathrm{p}>0.05)$ practice was not significantly associated with customer satisfaction. 
Table 6. Hypotheses Testing \& $\mathrm{R}^{2}$ Value

\begin{tabular}{|l|c|c|c|c|c|c|}
\hline Path of Hypotheses & P. Co-eff. & Std. Dev. & T-Value & P Value & Decision & $\mathbf{R}^{\mathbf{2}}$ \\
\hline SOCCSR -> CD & 0.254 & 0.069 & 3.684 & 0.000 & Supported & CD $=0.548$ \\
ENVCSR -> CD & 0.528 & 0.058 & 9.052 & 0.000 & Supported & 0.387 \\
SOCCSR -> CS & 0.328 & 0.081 & 4.027 & 0.000 & Supported & Moderate \\
ENVCSR -> CS & 0.071 & 0.077 & 0.929 & 0.353 & Not Supported & (Chin, \\
\cline { 1 - 5 } CD -> CS & 0.290 & 0.072 & 4.008 & 0.000 & Supported & $1998)$ \\
\hline
\end{tabular}

Moreover, there was a positive and significant association between customer demand and customer satisfaction $(\beta=0.290, \mathrm{t}=4.008$, $\mathrm{p}<0.05$ ) as shown in Figure 2. In the present study, exogenous latent variables (i.e. SOCCSR and ENVCSR) explained 54.8\% and 38.7\% variance of the endogenous latent variables i.e., customer demand (CD) and customer satisfaction (CS) respectively, which were moderate in proportion to Chin (1998) and substantial in accordance with Cohen (1988).

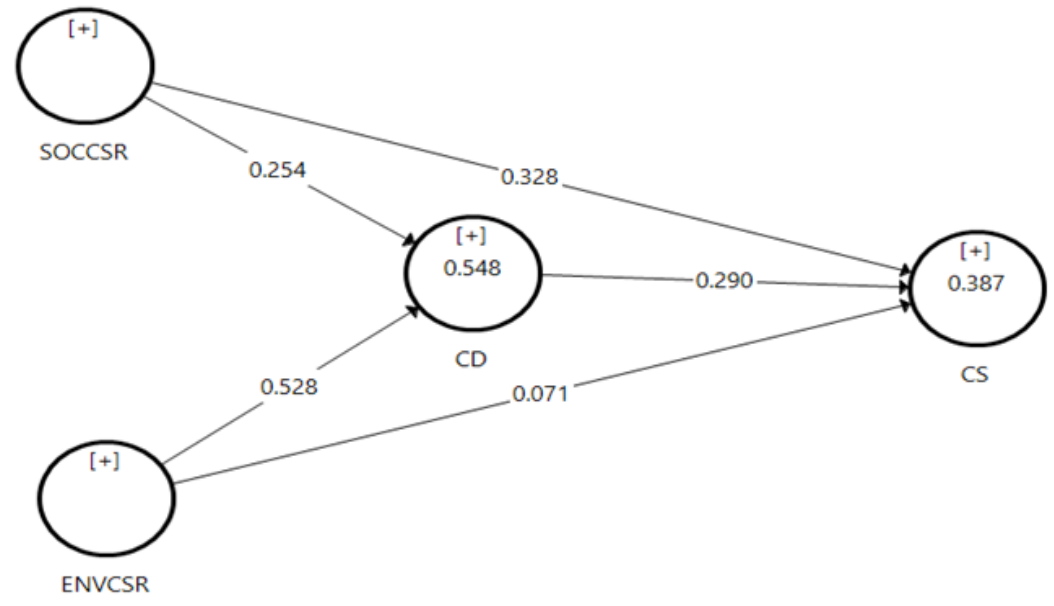

Figure 2. Path Analysis of the Conceptual Framework

\section{RESULTS, DISCUSSIONS}

Based on the findings, it has revealed that both the social CSR (SOCCSR) and environmental CSR (ENVCSR) are positively and significantly associated with customer demand (CD) and symbolised the ongoing demand of customers regarding socially and environmentally responsible hotel. Several prior studies have also emphasised about customer demand towards hotel CSR practices. For example, Bohdanowicz (2005) found customer demand as one of the key influential motivations for hotels to execute socially and environmentally friendly practices. The author also mentioned that owing to augmented customers' consciousness, hoteliers are becoming more responsive to their social and environmental, including eco-friendly products, services, and purchasing (Bohdanowicz, 2005). By the same token, Lindgreen et al. (2009) also emphasised on the customer demand towards responsible business practices in their study. According to them, as common group stakeholders, consumers are continuously creating pressures or increasing demands on the business firms when they are not behaving in a socially and environmentally responsible way.

The authors believe that if a firm's activities fail to influence consumers' moral values, firms may lose their prospective customers and business to other rivals. Moreover, if the hotels are not able to adopt socially and environmentally responsible practices, hoteliers might lose their prospective customers to other green operators (Butler, 2008). Equally, Delmas and Toffel (2004) and Le et al. (2006) found parallel outcomes where the authors have disclosed that customer demand has positive association on the responsible business practices of the organisation, particularly, environmental practices of the organization. On the other hand, social CSR has a significant positive association with customer satisfaction, while environmental CSR has an insignificant association with customer satisfaction.

A number of previous studies such as Chung et al., (2015), Senthikumar et al. (2011), and Basu and Palazzo (2008) found an analogous relationship that customer satisfaction and organization's CSR activities are positively related to each other. Regarding customer satisfaction, Senthikumar et al. (2011), pointed out that CSR practices provide positive effects on the aspects of organizational performance where the satisfaction of customers is one of them. Cherapanukorn and Focken (2014) claimed that due to the adoption of effective CSR practices, the hotel industry is achieving various substantial business-related benefits, including customer satisfaction for their eco-friendly services. Since in our study, only social CSR has a positive relationship with customer satisfaction, the environmen tal CSR has no significant association with customer satisfaction. Hence the study finding is comparable to Kasim (2004).

The author said that majority of customers choose a hotel based on price, quality of service, and physical attractiveness rather than environmental attributes. The customer preferred some non-green attributes such as individual soap cakes, fresh towels, and air conditioning, compared to the environmentally friendly alternatives. Moreover, in the Bangladesh context, due to the low level of education and awareness of the members of the society towards the environment and the shortage of promotion of CSR (Haque and Azmat, 2015; Aminuzzaman, 2010), the local tourists are not well-informed about the hotel CSR activities. And the concerns, as mentioned earlier, may also be the reason for not showing the significant relationship between environmental CSR (ENVCSR) and customer satisfaction (CS). This study also found a positive and significant association among customer demand (CD) and customer satisfaction (CS). Several earlier studies also explored similar pieces of evidence where Galbreath (2010) and Lee et al. (2012) said that organizations' CSR activates due to customer demand causing a higher degree of customer satisfaction. Equally, Liat et al. (2014) stated that hoteliers should focus on customer needs and requirements and integrate the hotel services that affect customer satisfaction, as their satisfaction plays a unique role in the firm's image.

\section{CONCLUSION}

The objective of this study is to assess the customer demand as well as customer satisfaction through social and environmental CSR practices based on tourist's' perception in the hotel sector of Bangladesh. Findings of the study reveal that customer demand is 
significantly associated with both the social and environmental CSR practices. This association indicates the continuing demand of customers concerning socially and environmentally responsible activities performed by the hotel sector. Besides, the study ou tcomes also establish the customer demand as one of the key influential motivations for hotels to execute socially and environmentally friendly practices. Likewise, the consequences of the study further explore the positive linkage between social CSR practice and customer satisfaction, though environmental CSR practice has an insignificant relationship with customer satisfaction. This study has also found a positive and significant association among customer demand and customer satisfaction. In this circumstance, the hoteliers should be more conscious about their customers' satisfaction as effective CSR activities can help the hoteliers attain the customers' satisfaction by fulfilling their expectations or demands. Organizations that operate in a socially and environmentally responsible manner and have a fame of fulfilling their responsibilities to various stakeholders create favourable image or reputation in the society.

Thus, the hotel managers should be aware of their internal and external CSR activities because these activities will create a better company image in the community. If hoteliers can fulfil their guests' expectations through their environmentally friendly services and activities, their satisfaction level will be proportionately high. If they are satisfied, they will revisit, and in return, the financial performance of the hotel will thrive. Moreover, in line with prior studies, since customer satisfaction and hotel CSR activities are positively related to each other it is believed that managers will be encouraged to employ more concern on their socially and environmentally friendly services in order to further their customers' satisfaction. Thus, satisfied customers will naturally keep revisiting the hotels in future. So hoteliers should focus on strengthening customer satisfaction which plays a unique role in company's image.

Eventually, like other studies, this study has a few limitations. The study puts overarching focus on the $4 \& 5$-star hotels from the hotel sector of Bangladesh and exclusively covers three cities from two divisions, namely Dhaka and Chittagong, out of eight divisions. As a result, the study may not represent the whole scenario of CSR practices in Bangladeshi hotel sector. Thus, future research can be conducted covering more cities to produce more generalized results. To gather survey data, the study surveys only the domesti c tourists. Thus, future research may include foreign tourists to explore their level of satisfaction and demand. Besides, this study has considered the social and environmental bottom line from Elkington's (1998) triple bottom line (TBL) approach. Hence, subsequent research may also consider the economic bottom line alongside the social and environmental bottom line.

\section{REFERENCES}

Ahmad, I., Shahzad, K., \& Gul, A. (2019). Mediating Role of Customer Satisfaction between Corporate Social Responsibility and Customer-Based Brand Equity. Business \& Economic Review, 11(1), 123-144.

Ahmed, N., \& Peerlings, J.H.M. (2009). Addressing Workers' Rights in the Textile and Apparel Industries: Consequences for the Bangladesh Economy. World Development, 37(3), 661-675.

Aminuzzaman, S.M. (2010). Environment policy of Bangladesh: A case study of an ambitious policy with implementation snag. South Asia Climate Change Forum, organized by Monash Sustainability Institute, Monash University, Australia, 59, 1-18.

Awang, Z.H., \& Jusoff, K. (2009). The effects of corporate reputation on the competitiveness of Malaysian telecommunication service providers. International journal of business and management, 4(5), 173-178.

Basu, K., \& Palazzo, G. (2008). Corporate social responsibility: A process model of sense making. Academy of management review, 33(1), $122-136$.

Belal, A.R. (2008). Corporate social responsibility reporting in developing countries: The case of Bangladesh. Aldershot: Ashgate Publishing.

Belal, A.R., \& Cooper, S. (2011). The absence of corporate social responsibility reporting in Bangladesh. Critical Perspectives on Accounting, 22 (7), 654-667.

Belal, A.R., \& Owen, D.L. (2007). The views of corporate managers on the current state of, and future prospects for, social reporting in Bangladesh: An engagement-based study. Accounting, Auditing \& Accountability Journal, 20(3), 472-494.

Belal, A.R., \& Roberts, R.W. (2010). Stakeholders' perceptions of corporate social reporting in Bangladesh. Journal of Business Ethics, 97(2), 311 -324.

Benavides-Velasco, C. A., Quintana-García, C., \& Marchante-Lara, M. (2014). Total quality management, corporate social responsibility and performance in the hotel industry", International Journal of Hospitality Management, 41, 77-87.

Berezan, O., Millar, M., \& Raab, C. (2014). Sustainable hotel practices and guest satisfaction levels. International Journal of Hospitality \& Tourism Administration, 15(1), 1-18.

Bigné, J.E., Alcañiz, J.E.B., Font, X., \& Andreu, L. (2000). Marketing of tourist destinations: analysis and development strategies. Madrid: ESIC Editorial.

Bohdanowicz, P. (2005). European hoteliers' environmental attitudes: Greening the business. Cornell hotel and restaurant administration quarterly, $46(2), 188-204$.

Bohdanowicz, P., \& Zientara, P. (2009). Hotel companies' contribution to improving the quality of life of local communities and the well-being of their employees. Tourism \& Hospitality Research, 9(2), 147-158.

Bowen, D., \& Clarke, J. (2002). Reflections on tourist satisfaction research: Past, present and future. Journal of Vacation Marketing, 8(4), 297-308.

Brown, T.J., \& Dacin, P.A. (1997). The company and the product: Corporate associations and consumer product responses. Journal of marketing, 61(1), 68-84.

Butler, J. (2008). The compelling 'hard case' for 'green' hotel development. Cornell Hospitality Quarterly, 49(3), $234-244$.

Chan, E.S.W. (2011). Implementing environmental management systems in small and medium sized hotels: obstacles. J. Hosp. Tour. Res., 35(1), 3-23.

Cherapanukorn, V., \& Focken, K. (2014). Corporate Social Responsibility (CSR) and Sustainability in Asian Luxury Hotels: Policies, Practices and Standards. Asian Social Science, 10(8), 198-209.

Chin, W.W. (1998). The partial least squares approach to structural equation modelling. Modern methods for business research, 295(2), 295-336.

Chung, K.H., Yu, J.E., Choi, M.G., \& Shin, J.I. (2015). The effects of CSR on customer satisfaction and loyalty in China: the moderating role of corporate image. Journal of Economics, Business and Management, 3(5), 542-547.

Chung, L.H., \& Parker, L.D. (2010). Managing social and environmental action and accountability in the hospitality industry: A Singapore perspective. Accounting Forum, 34, 46-53.

Clarkson, M.E. (1995). A stakeholder framework for analysing and evaluating corporate social performance. Academy of Management Review, 20 (1), 92117.

Cohen, J. (1988). Statistical power analysis for the behavioral sciences (2nd ed.). Hillsdale, NJ: Lawrence Erlbaum Associates.

Creyer, E.H., \& Ross Jr, W.T. (1997). Tradeoffs between price and quality: How a value index affects. Journal of Consumer Affairs, 31 (2), $280-302$.

Cuccia, T., \& Rizzo, I. (2011). Heritage and tourism: Theoretical and empirical issues. Tourismos: An International Multidisciplinary Journal of Tourism, $6(3), 37-56$.

de Leaniz, P.M.G., \& del Bosque, I.R. (2015). Sustainability: a competitive advantage in the tourism industry. Nova Science Publishers, Inc. ISBN: 978-163463-646-9. Chapter 3. Editor: Kerri Hayden Collins, In: Handbook on Tourism Development and Management.

Delmas, M., \& Toffel, M.W. (2004). Stakeholders and environmental management practices: an institutional framework. Business strategy and the Environment, 13(4), 209-222.

Elijido-Ten, E. (2007). Applying stakeholder theory to analyse corporate environmental performance: Evidence from Australian listed companies. Asian Review of Accounting, 15(2), 164-184.

Elkington, J. (1998). Partnerships from cannibals with forks: The triple bottom line of 21 st-century business. Environmental Quality Management, 8(1), 37-51.

ElTayeb, T.K., Zailani, S., \& Jayaraman, K. (2010). The examination on the drivers for green purchasing adoption among EMS 14001 certified companies in Malaysia. Journal of Manufacturing Technology Management, 21(2), 206-225.

Fatma, M., Rahman, Z., \& Khan, I. (2016). Measuring consumer perception of CSR in tourism industry: Scale development and validation. Journal of Hospitality and Tourism Management, 27, 39-48. 
Font, X., Walmsley, A., Cogotti, S., McCombes, L., \& Häusler, N. (2012). Corporate social responsibility: The disclosure-performance gap. Tourism Management, 33(6), 1544-1553.

Fornell, C., \& Larcker, D.F. (1981). Evaluating structural equation models with unobservable variables and measurement error. Journal of marketing research, $18(1), 39-50$.

Galbreath, J. (2010). Drivers of corporate social responsibility: The role of formal strategic planning and firm culture. British Journal of Management, 21(2), 511-525.

Gustin, M.E., \& Weaver, P.A. (1994). Do Guest Want Green Hotels? Lodging Hospitality, 70-72.

Hair Jr, J.F., Matthews, L.M., Matthews, R.L., \& Sarstedt, M. (2017). PLS-SEM or CB-SEM: updated guidelines on which method to use. International Journal of Multivariate Data Analysis, 1(2), 107-123.

Han, H., Kim, W., \& Hyun, S. S. (2011). Switching intention model development: Role of service performances, customer satisfaction, and switching barriers in the hotel industry. International Journal of Hospitality Management, 30(3), 619-629.

Haque, M.Z., \& Azmat, F. (2015). Corporate social responsibility, economic globalization and developing countries: a case study of the readymade garments industry in Bangladesh. Sustainability Accounting, Management and Policy Journal, 6(2), 166-189.

Henseler, J., Ringle, C.M., \& Sarstedt, M. (2015). A new criterion for assessing discriminant validity in variance-based structural equation modelling. Academy of Marketing Science. Journal, 43(1), 115.

Henseler, J., Ringle, C., \& Sinkovics, R. (2009). The use of partial least squares path modeling in international marketing. Advances in International Marketing (AIM), 20, 277-320.

Hsieh, Y.C. (2012). Hotel companies' environmental policies and practices: a content analysis of their web pages. International Journal of Contemporary Hospitality Management, 24(1), 97-121.

Hsu, K.T. (2012). The advertising effects of corporate social responsibility on corporate reputation and brand equity: Evidence from the life insurance industry in Taiwan. Journal of business ethics, 109(2), 189-201.

Inoue, Y.H., \& Lee, S.K. (2011). Effects of different dimensions of corporate social responsibility on corporate financial performance in tourism-related industries. Tourism Management, 32(4), 790-804.

Islam, M.A., \& Deegan, C. (2008). Motivations for an organization within a developing country to report social responsibility information: Evidence from Bangladesh. Accounting, Auditing \& Accountability Journal, 21(6), 850-874.

Jamali, D. (2008). A stakeholder approach to corporate social responsibility: A fresh perspective into theory and practice. Journal of business ethics, 82(1), 213-231.

Jovicic, D. (2011). The Environmental Management Systems and contemporary tourism development. Tourismos, 6(2), 377-391.

KamalulAriffin, N.S., Khalid, S.N.A., \& Wahid, N.A. (2013). The barriers to the adoption of environmental management practices in the hotel industry: a study of Malaysian hotels. Business Strategy Series, 14(4), 106-117.

Kang, J.S., Chiang, C.F., Huangthanapan, K., \& Downing, S. (2015). Corporate social responsibility and sustainability balanced scorecard: The case study of family-owned hotels. International Journal of Hospitality Management, 48, 124-134.

Kang, K.H., Lee, S., \& Huh, C. (2010). Impacts of positive and negative corporate social responsibility activities on company performance in the hospitality industry. International journal of hospitality management, 29(1), 72-82.

Karim, R.A. (2019). Drivers and Barriers of CSR Implementation in a Less Developed Country: The Case of Bangladesh's Hotel Sector. Unpublished Doctoral Thesis, Universiti Utara Malaysia, Malaysia.

Kasim, A. (2004). BESR in the hotel sector: A look at tourists' propensity towards environmentally and socially friendly hotel attributes in Pulau Pinang, Malaysia. International Journal of Hospitality \& Tourism Administration, 5(2), 61-83.

Kasim, A. (2015). Environmental management system (EMS). International Journal of Contemporary Hospitality Management, $27(6), 1233$ - 1253.

Khairat, G. \& Maher, A. (2012). Integrating sustainability into tour operator business: An innovative approach in sustainable tourism. Tourismos: An international multidisciplinary journal of tourism, 7(1), 213-233.

Kirk, D. (1998). Attitudes to environmental management held by a group of hotel managers in Edinburgh. International Journal of Hospitality Management, 17(1), 33-47.

Kotler, P., Bowen, J.T. \& Makens, J. (2006). Marketing for Hospitality and Tourism (4th ed.). NJ: Upper Saddle River.

Krejcie, R.V., \& Morgan, D.W. (1970). Determining sample size for research activities. Educational and Psychological Measurement, 30, 607-610.

Le, Y., Hollenhorst, S., Harris, C., McLaughlin, W., \& Shook, S. (2006). Environmental management: A study of Vietnamese hotels. Annals of Tourism Research, 33(2), 545-567.

Lee, Y.K., Lee, K.H., \& Li, D.X. (2012). The impact of CSR on relationship quality and relationship outcomes: A perspective of service employees. International Journal of Hospitality Management, 31(3), 745-756.

Liat, C.B., Mansori, S., \& Huei, C.T. (2014). The associations between service quality, corporate image, customer satisfaction, and loyalty: Evidence from the Malaysian hotel industry. Journal of hospitality marketing \& management, 23(3), 314-326.

Lindgreen, A., Swaen, V., \& Johnston, W. J. (2009). Corporate social responsibility: An empirical investigation of US organizations. Journal of business ethics, 85(2), 303-323.

Liu, I.D., \& Lin, C.F. (2011). The development of cultural tourism: A review of UK experience. Tourismos: An International Multidisciplinary Journal of tourism, 6(2), 363-376.

Luo, X., \& Bhattachara, C.B. (2006). Corporate Social Responsibility, Customer Satisfaction, and Market Value. Journal of Marketing, $70,1-18$.

Martínez, P., \& del Bosque, I.R. (2014). Sustainability dimensions: A source to enhance corporate reputation. Corporate Reputation Review, 17(4), 239-253.

McGehee, N.G., Wattanakamolchai, S., Perdue, R.R., \& Calvert, E.O. (2009). Corporate social responsibility within the US lodging industry: An exploratory study. Journal of Hospitality \& Tourism Research, 33(3), 417-437.

Mensah, I. (2014). Stakeholder pressure and hotel environmental performance in Accra, Ghana. Management of Environmental Quality: An International Journal, 25(2), 227-243.

Momin, M.A., \& Parker, L.D. (2013). Motivations for corporate social responsibility reporting by MNC subsidiaries in an emerging country: The case of Bangladesh. The British Accounting Review, 45(3), 215-228.

Mozes, M., Josman, Z., \& Yaniv, E. (2011). Corporate social responsibility organizational identification and motivation. Social Responsibility Journal. 7(2), 310-325.

Muttakin, M.B., \& Khan, A. (2014). Determinants of corporate social disclosure: empirical evidence from Bangladesh. Advances in Accounting, $30(1)$, 168-175.

Nielsen, M.E. (2005). The politics of corporate responsibility and child labour in the Bangladeshi garment industry. International Affairs, 81(3), 559-580.

Paul-Majumder, P., \& Begum, A. (2006). Engendering Garment Industry: The Bangladesh Context. Dhaka: The University Press Limited, Dhaka.

Pereira-Moliner, J., Font, X., Tarí, J.J., Molina-Azorin, J.F., Lopez-Gamero, M.D., \& Pertusa-Ortega, E.M. (2015). The Holy Grail: environmental management, competitive advantage and business performance in the Spanish hotel industry. International Journal of Contemporary Hospitality Management, 27(5), 714-738.

Pirsch, J., Gupta, S., \& Grau, S.L. (2007). A framework for understanding corporate social responsibility programs as a continuum: An exploratory study. Journal of business ethics, 70(2), 125-140.

Robinot, E., \& Giannelloni, J.L. (2010). Do hotels'“green" attributes contribute to customer satisfaction?. Journal of Services Marketing. 24(2), 157 - 169.

Saeidi, S.P., Sofian, S., Saeidi, P., Saeidi, S. P., \& Saaeidi, S.A. (2015). How does corporate social responsibility contribute to firm financial performance? The mediating role of competitive advantage, reputation, and customer satisfaction. Journal of business research, 68(2), 341-350. 
Saunders, M., Lewis, P., \& Thornhill, A. (2012). Research methods for business students (6 ${ }^{\text {th }}$ ed.). Harlow, England: Pearson Education.

Sekaran, U. (2003). Research method for business: A skill building approach (4th ed.). NY: John Wiley \& Sons, Inc.

Senthikumar, N., Ananth, A., \& Arulraj, A. (2011). Impact of corporate social responsibility on customer satisfaction in banking service. African Journal of Business Management, 5(7), 3028-3039.

SitiNabiha, A.K., Wahid, N.A., \& KamalulAriffin, N.S. (2010). Drivers for the adoption of environmental management practices in the hotel industry: An institutional perspective. Academy of Taiwan Business Management Review, 6(3), 20-28.

Tingchi Liu, M., Anthony Wong, I., Shi, G., Chu, R., \& L. Brock, J. (2014). The impact of corporate social responsibility (CSR) performance and perceived brand quality on customer-based brand preference. Journal of Services Marketing, 28(3), 181-194.

Torreli, C.J., Monga, A.B., \& Kaikati, A.M. (2011). Doing poorly by doing good: Corporate social responsibility and brand concepts. Journal of Consumer Research, 38(5), 948-963.

Ullah, M.H., \& Rahman, M.A. (2015). Corporate social responsibility reporting practices in banking companies in Bangladesh: Impact of regulatory change. Journal of Financial Reporting and Accounting, 132, 200-225.

Vinzi, V.E., Chin, W.W., Henseler, J., \& Wang, H. (2010). Perspectives on partial least squares. In Handbook of partial least squares (pp. 1-20), Berlin, Heidelberg: Springer.

Yang, X., \& Rivers, C. (2009). Antecedents of CSR practices in MNCs' subsidiaries: A stakeholder and institutional perspective. Journal of business ethics, 86(2), 155-169.

Yusof, Z. B., \& Jamaludin, M. (2013). Green approaches of Malaysian green hotels and resorts. Procedia-Social and Behavioral Sciences, 85, $421-431$.

Zhu, Q., Liu, J., \& Lai, K.H. (2016). Corporate social responsibility practices and performance improvement among Chinese national state-owned enterprises", International Journal of Production Economics, 171, 417-426.

Zupan, S., \& Milfelner, B. (2014). Social responsibility, motivation and satisfaction: Small hotels guests' perspective. Kybernetes, 43(3/4), 513-528.

*** BPC, (2007). Bangladesh Tourism Vision 2020. Morshed, M.M.R. (edited), Dhaka, Bangladesh published by the Bangladesh Parjatan Corporation, Dhaka, Bangladesh.

*** UNWTO (January 21, 2019). UNWTO World Tourism Barometer and Statistical Annex. Volume 17, Issue 1. Retrieved from: https://www.eunwto.org/doi/abs/10.18111/wtobarometereng.2019.17.1.1?journalCode=wtobarometereng 